\title{
Dermal absorption of vaporous and liquid 2-methoxyethanol and 2-ethoxyethanol in volunteers
}

\author{
Sanja Kežić, Karin Mahieu, Aart C Monster, Frederik A de Wolff
}

\begin{abstract}
Objectives-To estimate dermal absorption of vaporous and liquid 2-methoxyethanol (ME) and 2-ethoxyethanol (EE) in volunteers.

Methods-Five volunteers (two men and three women) were dermally exposed to vaporised and liquid ME and EE. Dermal exposure on an area of about $1000 \mathrm{~cm}^{2}$ (forearm and hand) to vapours of $M E$ and EE (4000 $\mathrm{mg} / \mathrm{m}^{3} \mathrm{ME}$ and $3700 \mathrm{mg} / \mathrm{m}^{3} \mathrm{EE}$ ) lasted for 45 minutes. Duration of exposure to liquid $M E$ and $E E$ on an area of 27 $\mathrm{cm}^{2}$ (forearm) was 15 minutes. Dermal uptake was assessed by measurement of the main metabolites in urinary methoxyacetic acid (MAA) and ethoxyacetic acid (EAA). For each volunteer, excretion of metabolites was compared with a reference inhalatory exposure.
\end{abstract}

Results-Mean (SD) absorption rates of $M E$ and EE vapour were 36 (11) and 19 (6) $\mathrm{cm} / \mathrm{h}$ respectively. The mean (SD) absorption rates of the liquid $M E$ and $E E$ amounted to $2.9(2.0)$ and $0.7(0.3)$ $\mathbf{m g} / \mathrm{cm}^{2} . \mathbf{h}$.

Conclusions-Vaporised and liquid ME and EE are readily absorbed through the skin. In the combined inhalatory and dermal exposure when whole body surface is exposed to vapour, the uptake through the skin is estimated to be $55 \%$ of the total uptake of ME and $42 \%$ of EE. Dermal uptake resulting from skin contact of both hands and forearms (about $2000 \mathrm{~cm}^{2}$ ) with liquid $M E$ and $E E$ for 60 minutes would exceed inhalatory uptake of the eight hour occupational exposure limit by 100 times at $16 \mathrm{mg} / \mathrm{m}^{3}$ of $M E$ and 20 times at $19 \mathrm{mg} / \mathrm{m}^{3}$ of EE. The substantial skin uptake of $M E$ and $E E$ indicates that in assessing the health risks biological monitoring and use of biological exposure indices are preferable to environmental monitoring.

(Occup Environ Med 1997;54:38-43)

Keywords: 2-methoxyethanol; 2-ethoxyethanol, dermal exposure

Although often comprising $<10 \%$ of the final product, 2-methoxyethanol (ME) and 2-ethoxyethanol (EE) are key ingredients in water or solvent based paints and coatings and industrial and domestic hard surface cleaning products. ${ }^{1}$ The usefulness of glycol ethers can be attributed to their physical properties, particularly their miscibility or high solubility in water and organic solvents, and their low vapour pressure. Studies on rodents indicate that $\mathrm{ME}$ and $\mathrm{EE}$ are compounds causing teratogenic, fetotoxic, haematotoxic, and testicular effects. ${ }^{1}$ The toxic metabolites of ME and $\mathrm{EE}$ are the corresponding alkoxyacetic acids, methoxyacetic acid (MAA) and ethoxyacetic acid (EAA).$^{2-4}$ In humans, $85 \cdot 5 \%$ of absorbed ME is excreted as urinary MAA with a half life of 77 hours. $^{4}$ On average, within 42 hours, $22 \%$ of absorbed EA was excreted as EAA with a mean (SD) half life of $42(4 \cdot 7)$ hours. $^{3}$

The main concern for human exposure is the occupational environment. The occupational exposure limits (OEL) of $\mathrm{ME}$ and $\mathrm{EE}$ are set in The Netherlands ${ }^{5}$ and United States ${ }^{6}$ at $5 \mathrm{ppm}$ (16 and $19 \mathrm{mg} / \mathrm{m}^{3}$, respectively). A skin notation assigned to $\mathrm{ME}$ and $\mathrm{EE}$ in these OEL documents implies that skin absorption might be an important route of entry.

Despite hard evidence that both glycol ethers as liquids are readily absorbed through human skin in vitro ${ }^{7}$ there are few human data on skin absorption of $\mathrm{ME}$ and $\mathrm{EE}$ in the liquid as well as in the vapour phase. Human data for skin uptake of another glycol ether 2-butoxyethanol have been published, ${ }^{8}{ }^{9}$ reporting that dermal exposure to 2-butoxyethanol, both liquid and vapour, was even more important than respiratory uptake. The purpose of this study was, therefore, to estimate the percutaneous absorption of $\mathrm{ME}$ and $\mathrm{EE}$ in volunteers under controlled experimental conditions.

\section{Subjects and methods}

SUBJECTS

The volunteers (two men and three women) ranged in age from 22 to 25 . All were without a history of serious diseases and their skins appeared normal. None of them took medicines or alcohol from at least 12 hours before exposure until the end of collection of urine. The experimental protocol was submitted to and approved by the medical ethics committee of the Academic Medical Center, University of Amsterdam. An informed consent form was signed by each subject.

Given the very long half life of MAA (74 hours) ${ }^{4}$ and of EAA (44 hours), ${ }^{3}$ the period between the two exposures in each volunteer was at least three weeks.

GENERATION OF GLYCOL ETHER VAPOUR Medical air at a flow rate of about $31 / \mathrm{min}$ 
from a compressed air cylinder was led through a bottle filled with neat ME or EE. The vapour stream was led through teflon tubes into and out of the exposure cylinder.

\section{EXPERIMENTAL SETTING}

\section{Dermal exposure to vapour and liquid}

The volunteer was situated in a clean air cabin with a slightly increased pressure to avoid additional inhalatory exposure. The exposure lasted for 45 minutes. The arm of the subject was the only part of the body outside the cabin. During the vapour exposure experiments, the subject placed the lower arm into the exposure cylinder into which the glycol ether vapour was led. The exposure cylinder (volume $6.5 \mathrm{l}$ ) was provided with one large opening for the forearm and five small openings of about $3 \mathrm{~mm}$ internal diameter: two inlets, two outlets, and an opening for the vapour sampling. The vapour concentrations of $M E$ and $E E$ were about 10 times below the saturation concentration. To minimise the influence of temperature and humidity in the cylinder on the skin absorption and to prevent condensation on the skin, the flow of $\mathrm{ME}$ and $\mathrm{EE}$ of about $31 / \mathrm{min}$ was used. The temperature varied from $22^{\circ} \mathrm{C}$ to $25^{\circ} \mathrm{C}$ and the relative humidity from $60 \%$ to $65 \%$. To avoid contamination of inhaled air through leakage, the opening in the cylinder and on the cabin were provided with cuffs. The concentrations of $\mathrm{ME}$ and $\mathrm{EE}$ in the cylinder were measured every five minutes throughout exposure.

During exposure to liquid $\mathrm{ME}$ and $\mathrm{EE}$, a glass chamber with an area of $27 \mathrm{~cm}^{2}$ was placed on the volar forearm and filled with $\mathrm{ME}$ or EE. After 15 minutes the exposure vessel was removed and the remaining solvent gently wiped off with a tissue. At the end of exposure the subject stayed for another 15 minutes in the cabin to allow the glycol ether to evaporate from the skin surface and to prevent possible inhalatory uptake.

\section{Inhalatory exposure}

Each volunteer was exposed during four periods of 15 minutes to a concentration of about three times the current OEL value in The Netherlands (16 and $19 \mathrm{mg} / \mathrm{m}^{3}$ for $M E$ and EE respectively). The time between the exposures was 10 minutes. Volunteers were in a sitting position and inhaled through a mouthpiece with a one way valve connected to a Tedlar (DuPont, Delaware, USA) bag containing $\mathrm{ME}$ and EE. During exposure the total amount of exhaled air was collected in another Tedlar bag. To prevent condensation of water in the exhaled air bag, a cold water trap (held at $0^{\circ} \mathrm{C}$ ) was placed between the mouthpiece and exhaled air bag. To correct for the amount of $\mathrm{ME}$ and $\mathrm{EE}$ possibly absorbed in the water trap, we measured the amount of $\mathrm{ME}$ and $\mathrm{EE}$ absorbed in the condensate in the cold trap after consecutive 15 minute exposures of four subjects; this amount was taken into account when calculating the respiratory uptake. To determine the actual exposure concentration, air samples were taken from the inhalation bag before and during exposure from a point situated in the system before the mouthpiece.

\section{Urine collection}

All urine was collected for the first two days; for practical reasons, on days three to five only a morning and last evening sample were taken. One person collected all urine for seven days. For each sample, volume, creatinine, and specific gravity were measured and the samples were stored at $-20^{\circ} \mathrm{C}$ until analysis.

\section{Analysis}

Analysis of inhaled and exhaled air was performed by gas chromatography. Air samples were injected with gas tight syringes into a gas chromatograph.

The MAA and EAA in urine were measured by a slightly modified version of the method of Groesenken et al..$^{10}$

To $100 \mu$ l urine $25 \mu$ l butoxyacetic acid (20 $\mathrm{mg} / \mathrm{l}$ )(internal standard) and $100 \mu \mathrm{l}$ phosphate buffer $(\mathrm{pH}=7)$ were added. Thereafter, samples were left at $60^{\circ} \mathrm{C}$ under slightly reduced pressure $(20 \mathrm{~mm} \mathrm{Hg})$ to evaporate to dryness (about 20 minutes). After cooling down to room temperature $500 \mu \mathrm{l} 5 \%$ derivatisation reagent $(2,3,4,5,6$-pentafluorobenzyl bromide) (Aldrich Chemie, Germany) in methanol was added. Derivatisation was allowed to proceed for three hours at $70^{\circ} \mathrm{C}$; after cooling down to room temperature, $500 \mu \mathrm{l}$ water was added then $500 \mu \mathrm{l} \mathrm{n}$-hexane. Samples were vortexed for one minute and then centrifuged for two minutes at $3000 \mathrm{~g}$. One $\mu \mathrm{l}$ hexane extract was injected into the gas chromatograph. Under these conditions, the detection limit of the method was $10 \mu \mathrm{g} / 1$ for both MAA and EAA.

Gas chromatographic conditions for the analysis of metabolites in urine

The gas chromatograph used was a Hewlett Packard Model 5890 A, equipped with an electron capture detector and a CP-SIL-13CB column (25 m; 0.25 mm internal diameter; film thickness $0.2 \mu \mathrm{m}$ ) (Chrompack, Middelburg, The Netherlands). Nitrogen was used as the carrier gas at a flow rate of $1 \mathrm{ml} / \mathrm{min}$. The oven temperature was initially set at $60^{\circ} \mathrm{C}$, increased to $166^{\circ} \mathrm{C}$ at a rate of $15^{\circ} \mathrm{C} / \mathrm{min}$, and subsequently to $200^{\circ} \mathrm{C}$ at a rate of $70^{\circ} \mathrm{C} / \mathrm{min}$ and the column temperature was then kept at $200^{\circ} \mathrm{C}$ for 10 minutes.

Gas chromatographic conditions for the analysis of inhaled and exhaled air

The gas chromatograph used was a Carlo Erba Mega 5000 (Interscience, The Netherlands) equipped with a flame ionisation detector and a DB-WAX column $(30 \mathrm{~m} ; 0.53 \mathrm{~mm}$ internal diameter; $1 \mu \mathrm{m}$ film thickness) (J and W Scientific). The analysis was performed isothermally at $80^{\circ} \mathrm{C}$.

\section{Measurement of skin area}

The skin area of the forearm exposed to vapour was measured with the formula for calculation of the curved area of the frustum of a right cone. ${ }^{11}$ The area of the hand was measured as 
Table 1 Inhalatory exposure to $M E$ and $E E$ (4 times for 15 minutes): exposure conditions, respiratory retention, and uptake of $M E$ and $E E$ and $48 \mathrm{~h}$ cumulative urinary excretion of $M A A$ and $E A A$

\begin{tabular}{|c|c|c|c|c|c|c|c|c|c|c|}
\hline \multirow[b]{2}{*}{ Subject } & \multicolumn{2}{|c|}{$\begin{array}{l}\text { Exposure } \\
\left(\mathrm{mg} / \mathrm{m}^{3}\right)\end{array}$} & \multicolumn{2}{|c|}{$\begin{array}{l}\text { Respiratory } \\
\text { retention (\%) }\end{array}$} & \multicolumn{2}{|c|}{$\begin{array}{l}\text { Inhalatory } \\
\text { uptake, } \\
U_{\text {inh }}(m g)\end{array}$} & \multicolumn{2}{|c|}{$\begin{array}{l}M A A \\
(E A A)_{i n h, 48 h} \\
(m g)\end{array}$} & \multicolumn{2}{|c|}{$\begin{array}{l}\text { Inhalatory uptake } \\
\text { extrapolated to } \\
8 \mathrm{~h} \text { exposure at } \\
\text { OEL (mg) }\end{array}$} \\
\hline & $M E$ & $E E$ & $M E$ & $E E$ & $M E$ & $E E$ & $M A A$ & $E A A$ & $M E$ & $E E$ \\
\hline $\begin{array}{l}1 \\
2 \\
3 \\
4 \\
5 \\
\text { Mean } \\
\text { SD }\end{array}$ & $\begin{array}{c}41 \\
39 \\
44 \\
44 \\
42 \\
42 \\
2 \cdot 2\end{array}$ & $\begin{array}{c}52 \\
46 \\
60 \\
49 \\
59 \\
53 \\
5.9\end{array}$ & $\begin{array}{r}85 \\
80 \\
77 \\
92 \\
67 \\
80 \\
9\end{array}$ & $\begin{array}{r}85 \\
75 \\
75 \\
86 \\
86 \\
81 \\
6\end{array}$ & $\begin{array}{c}18 \\
18 \\
18 \\
23 \\
16 \\
19 \\
2.6\end{array}$ & $\begin{array}{c}23 \\
20 \\
24 \\
24 \\
29 \\
24 \\
3 \cdot 2\end{array}$ & $\begin{array}{l}3.3 \\
1.2 \\
2 \cdot 4 \\
3 \cdot 1 \\
3.7 \\
2.7 \\
0.98\end{array}$ & $\begin{array}{l}5 \cdot 9 \\
1.8 \\
5 \cdot 2 \\
5 \cdot 3 \\
6 \\
4.8 \\
1.8\end{array}$ & $\begin{array}{c}54 \\
54 \\
54 \\
69 \\
48 \\
57 \\
7 \cdot 8\end{array}$ & $\begin{array}{c}67 \\
58 \\
70 \\
70 \\
84 \\
70 \\
9 \cdot 3\end{array}$ \\
\hline
\end{tabular}

follows: the subject put on a rubber glove which fitted as well as possible without stretching on the hand. The area was then assessed by comparing the weights of the glove and of a piece of glove of a known area.

\section{Calculation of uptake}

The respiratory uptake $\left(U_{\text {inh }}\right)$ and dermal uptake $\left(\mathrm{U}_{\text {der,vap }}\right.$ and $\mathrm{U}_{\text {der,liq }}$ ) of $\mathrm{ME}$ and $\mathrm{EE}$ was calculated from the equations (1) and (2):

$$
\mathrm{U}_{\mathrm{inh}}(\mathrm{mg})=\left(\mathrm{c}_{\mathrm{inh}}-\mathrm{c}_{\mathrm{exh}}\right) \times \mathrm{V}
$$

where $c_{i n h}=$ concentration $\mathrm{ME}$ or $\mathrm{EE}$ in inhaled air bag; $c_{\text {exh }}=$ concentration in exhaled air bag (corrected for the amount absorbed in the water trap); $\mathrm{V}=$ volume inhaled ( $=$ exhaled) air; and

$$
\begin{gathered}
\mathrm{U}_{\text {der }}(\mathrm{mg})=(\text { MAA(EAA) })_{\text {der }, 48-\mathrm{h}} / \\
\text { MAA(EAA } \left.)_{\text {inh, } 48 \mathrm{~h}}\right) \times \mathrm{U}_{\text {inh }}
\end{gathered}
$$

where $\mathrm{MAA}(\mathrm{EAA})_{\mathrm{der}, 48 \mathrm{~h}}=$ amount of excreted MAA(EAA) in urine during the 48 hours after dermal exposure; MAA(EAA) ${ }_{\text {inh, } 48 \mathrm{~h}}=$ amount of excreted MAA(EAA) in urine during the 48 hours after inhalatory exposure.

\section{Permeability parameters}

Exposure to vapour-The absorbtion rate $(\mathrm{cm} / \mathrm{h})$ was calculated by dividing the absorbed amount of $\mathrm{ME}$ and $\mathrm{EE}$ ( $\mathrm{U}_{\text {der,vap }}$ ) ( $\mathrm{mg}$ ) by the exposed area $\left(\mathrm{cm}^{2}\right)$, the duration of exposure (h), and the exposure concentration $\left(\mathrm{mg} / \mathrm{cm}^{3}\right)$.

Exposure to liquid-The dermal penetration rate (dermal flux) $\left(\mathrm{mg} / \mathrm{cm}^{2} . \mathrm{h}\right)$ was calculated by dividing the total absorbed amount $\left(U_{\text {der,liq }}\right)(\mathrm{mg})$, by the skin exposure area $\left(\mathrm{cm}^{2}\right)$ and the exposure duration $(\mathrm{h})$.

\section{Results}

Table 1 shows the experimental conditions of inhalatory exposure to $\mathrm{ME}$ and EE. For each volunteer, the calculated respiratory uptake $\left(\mathrm{U}_{\text {inh }}\right)$ of $M E$ and $E E$ and the 48 hour cumulative excretion of the corresponding acid metabolite are presented along with the respiratory uptake and retention defined as $\left(\mathrm{C}_{\mathrm{inh}}\right.$ $\left.\mathrm{C}_{\text {exh }} / \mathrm{C}_{\text {inh }}\right) \times 100 \%$.

Estimation of dermal uptake of vaporised and liquid $M E$ and $E E$ was based on the 48 hour MAA and EAA urinary excretion,

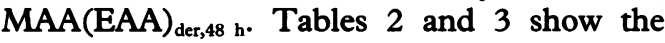
amounts absorbed dermally and calculated on an individual basis by comparison with a reference inhalatory exposure and exposure conditions. Tables 2 and 3 also show the permeability parameters for $\mathrm{MA}$ and EA vapour (absorbtion rate, $\mathrm{cm} / \mathrm{h}$ ) and for liquid (absorption rate, $\mathrm{mg} / \mathrm{cm}^{2} . \mathrm{h}$ ). The results indicate that $M E$ vapour penetrated the skin faster then $\mathrm{EE}$; the absorbtion rate for $\mathrm{ME}$ amounted to $36 \mathrm{~cm} / \mathrm{h}$ and to $19 \mathrm{~cm} / \mathrm{h}$ for EE (table 2). The difference in penetration between $M E$ and $\mathrm{EE}$ is even more pronounced after exposure to liquid; the absorption rate amounted to 2.9 for $\mathrm{ME}$ and $0.7 \mathrm{mg} / \mathrm{cm}^{2} . \mathrm{h}$ for EE (table 3).

\begin{tabular}{|c|c|c|c|c|c|c|c|c|c|c|c|c|c|c|}
\hline & \multicolumn{2}{|c|}{$\begin{array}{l}\text { Exposure } \\
\left(m g / m^{3}\right)\end{array}$} & \multicolumn{2}{|c|}{$\begin{array}{l}\text { Exposed area } \\
\left(\mathrm{cm}^{2}\right)\end{array}$} & \multicolumn{2}{|c|}{$\begin{array}{l}M A A \\
(E A A)_{d e r, 48 h} \\
(m g)\end{array}$} & \multicolumn{2}{|c|}{$\begin{array}{l}\text { Dermal } \\
\text { uptake } U_{\text {der }} \\
(m g)\end{array}$} & \multicolumn{2}{|c|}{$\begin{array}{l}\text { Absorbtion } \\
\text { rates } \\
(\mathrm{cm} / \mathrm{h})\end{array}$} & \multicolumn{2}{|c|}{$\begin{array}{l}\text { Dermal uptake } \\
\text { extrapolated to } \\
8 \mathrm{~h} \text { whole body } \\
\text { exposure at } \\
\text { OEL (mg) }\end{array}$} & \multicolumn{2}{|c|}{$\begin{array}{l}\text { Dermal/total } \\
\text { uptake } \\
(\%)\end{array}$} \\
\hline & $M E$ & $E E$ & $M E$ & $E E$ & $M A A$ & $E A A$ & $M E$ & $E E$ & $M E$ & $E E$ & $M E$ & $E E$ & $M E$ & $E E$ \\
\hline $\begin{array}{l}1 \\
2 \\
3 \\
4 \\
5 \\
\text { Mean } \\
\text { SD }\end{array}$ & $\begin{array}{l}3835 \\
5782 \\
3082 \\
6190 \\
5032 \\
4854 \\
1307\end{array}$ & $\begin{array}{r}2959 \\
4458 \\
2520 \\
4600 \\
3705 \\
3648 \\
910\end{array}$ & $\begin{array}{r}954 \\
905 \\
1210 \\
1032 \\
1086 \\
1037 \\
119\end{array}$ & $\begin{array}{r}868 \\
883 \\
1134 \\
1228 \\
1086 \\
1040 \\
159\end{array}$ & $\begin{array}{r}12 \\
10 \\
18 \\
30 \\
15 \\
17 \\
8\end{array}$ & $\begin{array}{r}11 \\
4 \\
14 \\
24 \\
7 \\
12 \\
8\end{array}$ & $\begin{array}{r}67 \\
153 \\
137 \\
219 \\
66 \\
128 \\
64\end{array}$ & $\begin{array}{r}42 \\
39 \\
67 \\
109 \\
35 \\
58 \\
31\end{array}$ & $\begin{array}{l}27 \\
40 \\
49 \\
46 \\
16 \\
36 \\
14\end{array}$ & $\begin{array}{r}22 \\
13 \\
31 \\
19 \\
12 \\
19 \\
8\end{array}$ & $\begin{array}{r}40 \\
92 \\
82 \\
131 \\
40 \\
77 \\
38\end{array}$ & $\begin{array}{r}40 \\
37 \\
64 \\
104 \\
33 \\
55 \\
29\end{array}$ & $\begin{array}{l}42 \\
63 \\
60 \\
66 \\
45 \\
55 \\
11\end{array}$ & $\begin{array}{l}37 \\
39 \\
48 \\
60 \\
28 \\
42 \\
12\end{array}$ \\
\hline
\end{tabular}

Table 2 Dermal exposure to vaporised $M E$ and $E E$ for 45 min: exposure conditions, $48 h$ cumulative urinary excretion of $M A A$ and $E A A$ and calculated dermal uptake and absorbtion rates of $M E$ and $E E$

\begin{tabular}{|c|c|c|c|c|c|c|c|c|c|c|}
\hline & \multicolumn{2}{|c|}{$M A A(E A A)_{d e r, 48 h}(m g)$} & \multicolumn{2}{|c|}{$\begin{array}{l}\text { Dermal uptake, } \\
U_{\text {der }}(m g)\end{array}$} & \multicolumn{2}{|c|}{$\begin{array}{l}\text { Absorption rate } \\
\left(\mathrm{mg} / \mathrm{cm}^{2} . \mathrm{h}\right)\end{array}$} & \multicolumn{2}{|c|}{$\begin{array}{l}\text { Dermal uptake } \\
\text { extrapolated to } 1 \mathrm{~h} \\
\text { exposure and to } \\
\text { exposed area of } \\
2000 \mathrm{~cm}^{2}(\mathrm{mg})\end{array}$} & \multicolumn{2}{|c|}{$\begin{array}{l}\text { Dermal/inhalatory } \\
\text { uptake }(8 h, O E L)\end{array}$} \\
\hline & $M A A$ & $E A A$ & $M E$ & $E E$ & $M E$ & $E E$ & $M E$ & $E E$ & $M E$ & $E E$ \\
\hline $\begin{array}{l}1 \\
2 \\
3 \\
4 \\
5 \\
\text { Mean } \\
\text { SD }\end{array}$ & $\begin{array}{l}3.9 \\
2 \cdot 2 \\
2 \cdot 8 \\
2 \cdot 4 \\
2.8 \\
0.8\end{array}$ & $\begin{array}{l}0.8 \\
0.6 \\
0.9 \\
0.8 \\
1.7 \\
0.96 \\
0.43\end{array}$ & $\begin{array}{l}14 \\
35 \\
21 \\
10 \\
20 \\
11\end{array}$ & $\begin{array}{l}3 \\
7 \\
4 \\
4 \\
8 \\
5 \cdot 2 \\
2 \cdot 2\end{array}$ & $\begin{array}{l}2 \cdot 1 \\
5 \cdot 2 \\
3 \cdot 1 \\
1 \cdot 6 \\
2 \cdot 9 \\
2 \cdot 0\end{array}$ & $\begin{array}{l}0.4 \\
1.0 \\
0.6 \\
0.5 \\
1.1 \\
0.7 \\
0.3\end{array}$ & $\begin{array}{r}4144 \\
10360 \\
6216 \\
-\quad 2960 \\
5920 \\
3256\end{array}$ & $\begin{array}{r}888 \\
2072 \\
1184 \\
1184 \\
2368 \\
1539 \\
651\end{array}$ & $\begin{array}{r}76 \\
192 \\
115 \\
-62 \\
111 \\
58\end{array}$ & $\begin{array}{l}13 \\
36 \\
17 \\
17 \\
28 \\
22 \\
10\end{array}$ \\
\hline
\end{tabular}

Table 3 Exposure to liquid $M E$ and EE for 15 minutes: exposure conditions, cumulative urinary excretion of $M A A$ and $E A A$, and calculated dermal uptake and absorption rate of $M E$ and $E E$ 
Figure 1 Cumulative urinary excretion of $M A A$ after dermal and inhalatory exposure to vaporised $M E$.

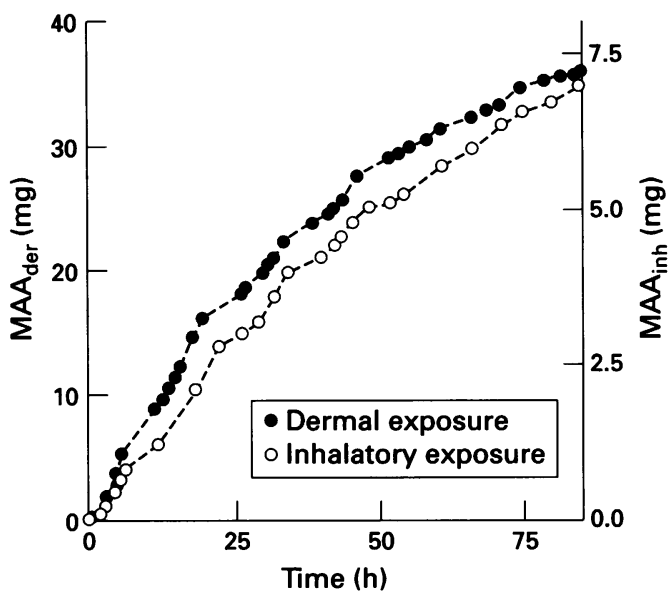

Figure 2 Cumulative urinary excretion of $E A A$ after dermal and inhalatory exposure to vaporised $E E$.

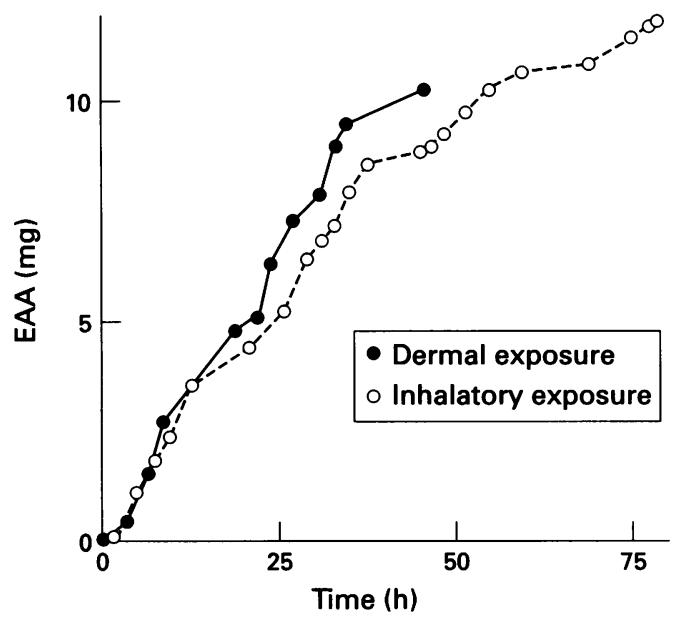

To compare dermal uptake and uptake by inhalation from the same atmosphere we extrapolated the amount of MAA(EAA) $)_{\text {der, } 48 \mathrm{~h}}$ in both experiments to the identical exposure conditions assuming constant absorbtion rates: eight hours of exposure at OEL ( $16 \mathrm{mg} / \mathrm{m}^{3} \mathrm{ME}$ and $\left.19 \mathrm{mg} / \mathrm{m}^{3} \mathrm{EE}\right)$. Assuming that the entire skin area of the body is exposed, the forearm surface area is linearly extrapolated to the whole body surface area of $1.8 \mathrm{~m}^{2}$ (tables 1 and 2).

To compare dermal uptake of liquid $\mathrm{ME}$ and EE with inhalatory uptake, we extrapolated the uptake determined in our study (exposed area of $27 \mathrm{~cm}^{2}$ and exposure duration of 15 minutes) to a skin area of $2000 \mathrm{~cm}^{2}$ (both forearms and hands) and exposure duration of 60 minutes. Table 3 shows this extrapolated uptake compared with the inhalatory uptake after exposure for eight hours at the OEL (table 1). These exposure conditions are proposed by the European Centre for Ecotoxicology and Toxicology of Chemicals (ECETOC) as a criterion for assigning a "skin notation" in the OEL documents. According to that criterion a skin notation should be applied if dermal uptake is $>10 \%$ of the eight hour inhalatory uptake at the OEL.

The use of inhalatory exposure as reference is based on the assumption that the toxicokinetics of ME and EE once absorbed in the systemic circulation is identical for both exposure routes. The excretion of both metabolites showed a similar pattern independent of expo-

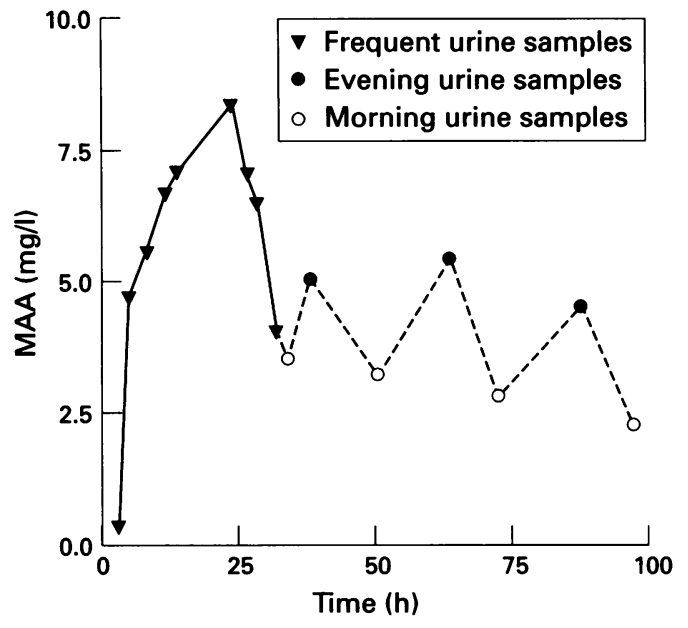

Figure 3 Urinary excretion of $M A A$ after dermal exposure to vaporised $M E$.

sure route: an initially fast increase in the concentration then slow and highly irregular excretion (figs 1-3). Before exposure neither MAA nor EAA was present in the urine in concentrations exceeding the detection limit of the analytical method $(0.01 \mathrm{mg} / \mathrm{l})$. The mean (SD) elimination half life calculated from the slope of the log linear excretion time curve 72 (24) hours for MAA and 44 (8) hours for EAA. Consequently, in morning urine samples lower concentrations were found; a day and night rhythm was illustrated for MAA after dermal exposure to $\mathrm{ME}$ vapour (fig 3). Correction for creatinine or specific density did not affect this excretion pattern. Slow urinary excretion of MAA and EAA is reflected in the shape of the cumulative excretion curves: even after seven days there was hardly any levelling off (measured in a person who collected all urine for seven days).

\section{Discussion}

Estimation of dermal uptake by comparison of urinary excretion of MAA and EAA after dermal and respiratory exposure is based on the assumption that their biokinetics is not affected by different routes of entry. The elimination pattern of MAA and EAA seemed to be similar for both exposure routes (figs 1 and 2) and it gave us the opportunity to measure dermal absorption by comparing it with a reference inhalatory exposure on an individual basis. Excretion of MAA and EAA was highly variable within individual people and there was a day and night rhythm; morning concentrations were always lower than those in the evenings (fig 3). The half lives were 72 hours for MAA and 42 hours for EAA and agreed closely with previously reported values of 77 and 42 hours for $\mathrm{ME}$ and $\mathrm{EE} .{ }^{34}$ As a consequence of such long half lives, the excretion of MAA and EAA was far from complete 48 hours after the start of exposure; on a molar equivalent basis only $12 \%$ and $14 \%$ of the dose was recovered within this period as MAA and EAA, respectively. This was lower than the reported values of $28 \%$ for $\mathrm{ME}^{4}$ and $23 \%$ for $\mathrm{EE}^{3}$ 
The long half life of MAA and EAA and a circadian excretion pattern could probably be explained by protein binding of MAA and EAA in blood or their reabsorption in the kidneys. Binding to proteins and elimination by saturable kinetics in the kidneys were reported by Corely and Bormett ${ }^{12}$ for butoxyacetic acid (BAA), a compound with a comparable chemical structure to MAA and EAA. A similar urinary excretion pattern, with a circadian variation and a long half life, was also reported by Monster et $a l^{13}$ for trichloroacetic acid, a metabolite of trichloroethylene. Circadian excretion rhythm is important if MAA and EAA are used as generally accepted biological exposure indices. A consistent sampling time has, therefore, to be applied.

Respiratory retention of both $\mathrm{ME}$ and $\mathrm{EE}$ was high, about $80 \%$, as could be expected from the very high blood/air partition coefficients of 32836 and 22093 for ME and EE, respectively. ${ }^{14}$ Respiratory retentions estimated in our study were somewhat higher than the values of $76 \%$ and $64 \%$ for $\mathrm{ME}$ and $\mathrm{EE}$ reported by Groesenken et al. ${ }^{34}$ These differences could be explained by different exposure conditions (mouth only in our study versus nose and mouth exposure in the studies of Groesenken et al. $^{34}$

This study showed that vaporised and liquid $\mathrm{ME}$ and EE are readily absorbed through the skin. The absorbtion rates into the skin normalised by cocentration of ME vapour is 36 $\mathrm{cm} / \mathrm{h}$ and $19 \mathrm{~cm} / \mathrm{h}$ for EE. Higher absorption of $\mathrm{ME}$ was more pronounced in exposure to liquid where an absorption rate of 2.9 for $\mathrm{ME}$ and $0.7 \mathrm{mg} / \mathrm{cm}^{2} . \mathrm{h}$ for $\mathrm{EE}$ was estimated. Theoretically, the same ratio in permeability of $M E$ and EE could be expected in exposure both to liquid and vapour. However, a high variation between people in both permeability parameters precludes speculation about the source of this discrepancy. Dugard and Walker ${ }^{7}$ reported that liquid $\mathrm{ME}$ has a higher skin damage ratio than EE. This could possibly affect the skin integrity, and consequently increase the absorption of $\mathrm{ME}$, in relation to EE. The absorption rate of liquid ME and EE estimated in our study is in close agreement with findings reported from the in vitro studies of Dugard and Walker ${ }^{7}$ who reported mean (SD) values of $2.82(2.63)$ for $\mathrm{ME}$ and 0.796 $(0.46) \mathrm{mg} / \mathrm{cm}^{2} . \mathrm{h}$ for EE.

In risk assessment it is important to estimate the relevance of skin uptake in relation to the other exposure routes. Inhalation exposure is assumed to be the most important uptake route for most organic solvents. However, $\mathrm{ME}$ and $E E$ penetrate the skin so easily that skin contact of both hands and forearms (about $2000 \mathrm{~cm}^{2}$ ) with liquid for one hour, greatly exceeds the respiratory uptake at OEL for eight hours (ME 100-fold and EE 20-fold). The question arises as to how realistic is such extensive skin contact with liquid $\mathrm{ME}$ and $\mathrm{EE}$ in occupational settings. It has to be stressed, however, that if spilling of ME and EE on clothing occurs, an even higher exposed area and exposure time can be expected. This exposure scenario $\left(2000 \mathrm{~cm}^{2}\right.$ exposure area for one hour) was proposed by the ECETOC ${ }^{15}$ as a criterion for assigning a skin notation. According to that criterion, a skin notation should be given if the dermal uptake under these conditions amounted to $>10 \%$ of the inhalatory uptake.

Dermal absorption of vapours is generally considered to be of minor importance compared with pulmonary uptake. However, it should be realised that a whole body skin area of $1.8 \mathrm{~m}^{2}$ confronted with a mean air velocity of $2 \mathrm{~km} / \mathrm{h}$ was swept by a volume of $28800 \mathrm{~m}^{3}$ in eight hours, ${ }^{15}$ considerably more than the corresponding inhaled volume of $10 \mathrm{~m}^{3}$. On the other hand, difference in the relative surface areas $\left(1 \cdot 8 \mathrm{~m}^{2}\right.$ for the skin $v 30-100 \mathrm{~m}^{2}$ for the lungs), ${ }^{16}$ percentages of the cardiac output ( $100 \%$ for the lungs $v 3 \%$ for the skin), and the distance that the compound must penetrate to reach the blood favour the lungs, generally speaking, as the primary site of absorption in a whole body exposure. However, our study shows that the skin is a significant uptake route for $\mathrm{ME}$ and $\mathrm{EE}$ vapour. If we assume whole body dermal and inhalatory exposure to vapour, the contribution of the skin to the total uptake would amount to $55 \%$ for $\mathrm{ME}$ and $42 \%$ for EE. Of course, this approach is simplified and some assumptions have been used in making these calculations. Firstly, that skin penetration characteristics of the forearms and hands (about $10 \%$ of the total body area) are representative for the whole body, and secondly that clothing and possibly higher temperature and humidity under the clothing does not notably affect skin penetration. It is well known, however, from several experimental studies, that these factors could have an impact on the skin permeability. ${ }^{17}$ Previously, Johanson and Boman ${ }^{8}$ reported that dermal uptake of butoxyethanol accounts for about $75 \%$ of the total uptake during whole body exposure to butoxyethanol vapour with a tendency towards increased percutaneous absorption rate under conditions of increased temperature and humidity $\left(33^{\circ} \mathrm{C}, 71 \%\right.$ relative humidity in comparison with $23^{\circ} \mathrm{C}$ and $29 \%$ relative humidity) although the differences were not significant. However, with physiologically based pharmacokinetics models, Corely and Bormett ${ }^{12}$ estimated the contribution of dermal uptake to be $21 \%$ of the total uptake, pointing out that the dermal uptake of butoxyethanol in the study of Johanson and Boman $^{8}$ was overestimated due to the method of calculating uptake. The contribution of $21 \%$ would be more consistent with the assumption that permeability of homologous glycol ethers decreases with the number of $\mathrm{C}$ atoms in the chain, as found in the present study and in the study of Dugard and Walker. ${ }^{7}$ Applying another mathematical model from the literature, ${ }^{18}$ based on the octanol/water partition coefficient, molecular weight and vapour pressures, we estimated contribution of whole body dermal uptake to be $32 \%, 40 \%$, and $61 \%$ of the total uptake for $\mathrm{ME}, \mathrm{EE}$, and $B E$, respectively. Although these values are of the same order of magnitude as our results, 
the permeability coefficient calculated with this model seems to increase with the number of $\mathrm{C}$ atoms and thus contrasts with our results and the in vitro study reported by Dugard and Walker. $^{7}$

In summary, results of the present study show that dermal absorption associated with exposure to $\mathrm{ME}$ and $\mathrm{EE}$ vapour and liquid is of major importance. In the mixed inhalatory and dermal exposure when the whole body surface is exposed to vapour, dermal uptake would contribute $55 \%$ of the total uptake for $\mathrm{ME}$ and $42 \%$ for EE. Skin contact of both hands and forearms for 15 minutes with liquid $M E$ and EE would considerably exceed the eight hour inhalatory uptake at the OEL. In monitoring exposure at the workplace, substantial skin uptake of $\mathrm{ME}$ and $\mathrm{EE}$ indicates that biological monitoring is to be preferred over environmental monitoring.

Also, the experimental set up used in the present study proved to be suitable for measurement of dermal absorption of chemical vapours and liquids in humans, providing the necessary data for the assessment of the health risks of exposure to these solvents.

1 National Institute for Occupational Safety and Health Occupational exposure to ethylene glycol monomethyl ether, ethylene glycol monoethyl ether, and their acetates. Cincinnati, OH: NIOSH, 1991.

2 Groesenken D, Veulemans H, Masschelein R. Respiratory uptake and elimination of ethylene glycol monoethyl ether after experimental human exposure. $\mathrm{Br} \mathcal{F}$ Ind $\mathrm{Med}$ 1986;43:544-9.

3 Groesenken D, Veulemans $H$, Masschelein R. Urinary excretion of ethoxyacetic acid after experimental human exposure to ethylene glycol monoethyl ether. $B r \mathcal{F}$ Ind Med 1986;43:615-9.

4 Groesenken D, Veulemans H, Masschelein R, Van Vlem E. Experimental human exposure to ethylene glycol monomethyl ether. Int Arch Occup Environ Health 1989 61:243-7.

5 De Nationale MAC-lijst. Den Haag: Arbeidsinspectie, 1994.

5 De Nationale MAC-lijst. Den Haag: Arbeidsinspectie, 1994. American Conference of Governmental Industrial
Hygienists. Threshold limit values for chemical substances Hygienists. Threshold limit values for chemical substances and physical agents and biolog

7 Dugard PH, Walker M. Absorption of some glycol ethers through human skin in vitro. Environ Health Perspect 1984;57:193-7.

8 Johanson G, Boman A. Percutaneous absorption of 2 butoxyethanol vapour in human subjects. $\mathrm{Br} \mathcal{F}$ Ind $\mathrm{Med}$ 1991;48:788-92.

9 Johanson G, Boman A, Dynesius B. Percutaneous absorption of 2-buthoxyethanol in man. Scand $\mathcal{f}$ Work Environ Health 1988;14:101-9.

10 Groesenken D, Veulemans H, Masschelein R, Van Vlem E. An improved method for the determination in urine of alkoxyacetic acids. Int Arch Occup Environ Health 1989; 61:249-54.

11 Hursh JB, Clarkson TW, Miles EF, Goldsmith LA. Percutaneous absorption of mercury vapour by men. Arch Environ Health 1989;44:122-7.

12 Corely RA, Bormett GA. Physiological based pharmacokinetics of 2-butoxyethanol and its major metabolite, 2butoxyacetic acid, in rats and humans. Toxicol Appl Pharmacol 1994;129:61-79.

13 Monster AC, Boersma G, Duba WC. Kinetics of trichloroethylene in repeated exposure of volunteers. Int Arch Occup Environ Health 1979;42:283-92.

14 Johanson G. Dynesius B. Liquid/air partition coefficients of six commonly used glycol ethers. $B r$ f Ind Med 1988;45: $561-4$.

15 European Centre for Ecotoxicology and Toxicology of Chemicals. Percutaneous absorption. Brussels: ECETOC, 1993.

16 International Commission on Radiological Protection. Report of the task group on reference man. New York: ICRP, 1975.

17 Scheuplein RJ, Blank I. Permeability of the skin. Physiological Reviews 1971;51:702-47.

18 Wilschut A, ten Berge WF, Robinson PJ, McKone TE. Estimating skin permeation. The validation of five mathematical skin permeation models. Chemosphere 1995;30: 1275-96. 